\title{
Metabolism by human endothelial cells of very low density lipoprotein subfractions isolated from Type 1 (insulin-dependent) diabetic patients
}

\author{
R. L. Klein and M. F. Lopes-Virella \\ Research Service, Ralph H. Johnson Department of Veteran Affairs Medical Center and Department of Medicine, Medical University of \\ South Carolina, Charleston, South Carolina, USA
}

\begin{abstract}
Summary. The very low density lipoprotein (VLDL) fraction was isolated from 11 normolipidaemic Type 1 (insulindependent) diabetic patients in good to fair glycaemic control and from 11 age-, sex- and race-matched, non-diabetic, control subjects. The rate of receptor-mediated degradation by human endothelial cells was significantly greater $(p<0.02)$ for the total VLDL fraction isolated from diabetic patients compared to control subjects and averaged $1008 \pm 300$ and $717 \pm 150 \mathrm{ng} \cdot \mathrm{mg}$ cell protein ${ }^{-1} \cdot 16 \mathrm{~h}^{-1}$, respectively. The total VLDL fraction was separated into three subfractions: VLDL-I, $S_{\mathrm{f}} 100-400\left(\mathrm{~S}_{\mathrm{f}}=\right.$ Svedberg units $)$; VLDL-II, $\mathrm{S}_{\mathrm{f}}$ 60-100; VLDL-III, $S_{\mathrm{f}} 20-60$. Rates of receptor-mediated degradation of VLDL-I and VLDL-II isolated from diabetic patients were significantly greater than the comparable subfraction isolated from control subjects and averaged $1023 \pm 279$ vs $361 \pm 122(p<0.01)$ and $433 \pm 70$ vs $294 \pm 70$ $\mathrm{ng} \cdot \mathrm{mg}$ cell protein ${ }^{-1} \cdot 16 \mathrm{~h}^{-1}(p<0.03)$, respectively. Rates of
\end{abstract}

receptor-mediated degradation of the V-III subfraction isolated from the two groups did not differ significantly. There were no significant differences in the chemical composition or in the plasma concentrations of the VLDL subfractions isolated from diabetic patients compared to control subjects. There was a significant increase in the apoprotein $\mathrm{E}$ content of VLDL-I $(p<0.01)$ and VLDL-II $(p<0.05)$ isolated from diabetic patients. There was a significant increase in the ratio of apoprotein $\mathrm{C}$ compared to apoprotein $\mathrm{E}(p<0.03)$ in VLDL-I isolated from control subjects compared to the diabetic patients. There were no significant differences in the apoprotein composition of VLDL-III isolated from the two groups.

Key words: Endothelial cells, very low density lipoprotein subfractions, diabetes mellitus, atherosclerosis.
There is an increased prevalence of atherosclerosis in patients with diabetes mellitus and vascular disease accounts for 70 to $80 \%$ of the deaths in diabetic patients [1-3]. Abnormalities of lipoprotein metabolism are intimately related to the development of atherosclerosis, and several abnormalities of lipoprotein metabolism have been described in diabetic patients. Most of these abnormalities have been described using cultured fibroblasts [4-6] or macrophages [7-11]. The endothelium of the arterial wall, however, plays an integral role in the maintenance of intravascular homeostasis and, therefore, in the development of atherosclerosis. Studies of lipoprotein interaction with endothelial cells are limited, however, particularly as they relate to diabetes.

Lipoproteins interact with endothelial cells like other peripheral cell types studied in culture by binding, internalization and degradation via receptor-mediated pathways [12-15]. Previous studies have shown that modifications of plasma lipoproteins due to the diabetic state alter the interaction of the lipoproteins with cell lipoprotein receptors.
The hyperglycaemia associated with diabetes results in the non-enzymatic glycation of apoproteins in LDL [16] and VLDL [17]. We have shown that glycation of LDL in vitro [7] or of apoprotein B ofLDL isolated from Type 1 (insulindependent) [8] or Type 2 (non-insulin-dependent) [10] diabetic patients, alters its interaction with macrophage lipoprotein receptors. VLDL isolated from diabetic patients also exhibit altered chemical compositions [9-11] and this may contribute to their abnormal interaction with cell lipoprotein receptors. Recent studies have shown that the alterations in the chemical composition of VLDL are influenced by the level of glycaemic controland are specific for the size of the VLDL [18].

Thus, we investigated if VLDL isolated from Type 1 diabetic patients would interact abnormally with human endothelial cells and if the abnormal interaction was associated with an altered composition of the VLDL. Furthermore, we investigated if the abnormal interaction and altered VLDL composition were specific for the size of the VLDL. 
Table 1. Clinical characteristics of Type 1 diabetic patients and control subjects

\begin{tabular}{|c|c|c|c|c|c|}
\hline Group & $\begin{array}{l}\text { Sex } \\
\text { (male:female) }\end{array}$ & $\begin{array}{l}\text { Race } \\
\text { (black: white) }\end{array}$ & $\begin{array}{l}\text { Age } \\
\text { (years) }\end{array}$ & $\begin{array}{l}\text { Duration } \\
\text { of diabetes } \\
\text { (years) }\end{array}$ & $\begin{array}{l}\text { Body mass index } \\
\left(\mathrm{kg} / \mathrm{m}^{2}\right)\end{array}$ \\
\hline $\begin{array}{l}\text { Diabetic } \\
\text { patients }\end{array}$ & $9: 2$ & $1: 10$ & $\begin{array}{l}33.4 \pm 2.8^{a} \\
(25-40)\end{array}$ & $\begin{array}{l}8.3 \pm 3.7 \\
(2-25)\end{array}$ & $\begin{array}{l}23.1 \pm 1.8 \\
(20.5-24.8)\end{array}$ \\
\hline $\begin{array}{l}\text { Control } \\
\text { subjects }\end{array}$ & $9: 2$ & $1: 10$ & $\begin{array}{l}34.2 \pm 3.6 \\
(22-41)\end{array}$ & - & $\begin{array}{l}26.3 \pm 2.2 \\
\left(21.3-32.8^{b}\right)\end{array}$ \\
\hline
\end{tabular}

${ }^{a}$ Values shown are mean \pm SEM and (range) for each population.

There was only one subject with BMI greater than $26 \mathrm{~kg} / \mathrm{m}^{2}$. This subject was normolipaemic and had only $9.5 \%$ of body weight contributed by fat

Table 2. Parameters of glycaemic control and plasma lipid levels in Type 1 diabetic patients and control subjects

\begin{tabular}{|c|c|c|c|c|c|c|c|}
\hline \multirow[t]{2}{*}{ Group } & \multirow{2}{*}{$\begin{array}{l}\mathrm{FPG} \\
(\mathrm{mol} / 1)\end{array}$} & \multirow{2}{*}{$\begin{array}{l}\mathrm{HbA}_{1 c} \\
(\%)\end{array}$} & \multirow{2}{*}{$\begin{array}{l}\text { Plasma } \\
\text { Chol } \\
(\mathrm{mol} / \mathrm{l})\end{array}$} & \multirow{2}{*}{$\begin{array}{l}\text { Plasma } \\
\text { TG } \\
(\mathrm{mol} / \mathrm{l})\end{array}$} & \multicolumn{3}{|c|}{ Lipoprotein chol (mol/l) } \\
\hline & & & & & VLDL & $\mathrm{LDL}$ & $\mathrm{HDL}$ \\
\hline $\begin{array}{l}\text { Diabetic } \\
\text { patients }\end{array}$ & $\begin{array}{l}13.7 \pm 2.6^{a} \\
(7.7-21.9)\end{array}$ & $\begin{array}{l}7.6 \pm 0.3 \\
(6.9-8.5)\end{array}$ & $\begin{array}{l}4.4 \pm 0.3 \\
(3.2-5.9)\end{array}$ & $\begin{array}{l}1.1 \pm 0.3 \\
(0.4-2.1)\end{array}$ & $\begin{array}{l}0.7 \pm 0.1 \\
(0.3-1.0)\end{array}$ & $\begin{array}{l}2.7 \pm 0.4 \\
(1.5-4.3)\end{array}$ & $\begin{array}{l}1.1 \pm 0.1 \\
(0.6-1.8)\end{array}$ \\
\hline $\begin{array}{l}\text { Control } \\
\text { subjects }\end{array}$ & $\begin{array}{l}5.5 \pm 0.3 \\
(4.8-6.3) \\
\end{array}$ & $\begin{array}{l}4.7 \pm 0.1 \\
(4.0-5.0) \\
\end{array}$ & $\begin{array}{l}4.7 \pm 0.2 \\
(4.1-5.5)\end{array}$ & $\begin{array}{l}1.3 \pm 0.2 \\
(0.7-2.4)\end{array}$ & $\begin{array}{l}0.8 \pm 0.2 \\
(0.3-1.6)\end{array}$ & $\begin{array}{l}2.9 \pm 0.3 \\
(2.1-3.7)\end{array}$ & $\begin{array}{l}1.0 \pm 0.1 \\
(0.7-1.5)\end{array}$ \\
\hline
\end{tabular}

"Values shown are mean \pm SEM and (range) for each group.

FPG, Fasting plasma glucose; Chol, cholesterol; TG, triglycerides

\section{Subjects and methods}

\section{Subjects}

Eleven patients with Type 1 diabetes with diagnoses based on the criteria established by the National Diabetes Data Group [19] and confirmed by plasma C-peptide levels of less than $0.5 \mathrm{ng} / \mathrm{ml}$ were recruited from the Private Diagnostic Clinic of the Medical University of South Carolina for this study. For every diabetic patient, an age-, sex-, and race-matched, non-diabetic control subject was recruited and blood was drawn on the same day from each member of the matched pair. Only normolipidaemic subjects were included in the study in order to exclude the potentially confounding effects of hypertriglyceridaemia on cell-lipoprotein interactions. Informed consent, as approved by the Institutional Review Board for Human Research of the Medical University of South Carolina, was obtained from each subject involved in the study.

None of the patients had proteinuria or other evidence of renal impairment. One patient had background retinopathy. No patient reported taking any medication except insulin. Additional clinical characteristics of the diabetic and control groups are shown in Table 1. Fasting plasma glucose, haemoglobin $\mathrm{A}_{1 \mathrm{c}}\left(\mathrm{Hb}_{1 \mathrm{c}}\right)$ and fasting lipid profile were determined for all subjects and these data are shown in Table 2. $\mathrm{HbA}_{1 \mathrm{c}}$ levels $(p<0.001)$ and fasting plasma glucose levels $(p<0.01)$ were significantly higher in the diabetic patients. There were no significant differences in any of the parameters of the lipid profile between control subjects and diabetic patients.

\section{Protocol}

A $450 \mathrm{ml}$ blood sample was collected from each subject after a $12-$ $14 \mathrm{~h}$ fast. This sample was used to isolate discrete subfractions of VLDL for metabolic studies and for the determination of VLDL subfraction composition. VLDL subfractions from each subject were radiolabelled with ${ }^{125} \mathrm{I}$, and the degradation of ${ }^{125} \mathrm{I}-\mathrm{VLDL}$ apoproteins by human endothelial cells was determined. Human endothelial cells were isolated from umbilical veins. The endothelial cells used for each experiment were isolated from an individual donor. Different donors were used for different experiments. Matched VLDL samples from diabetic patients and control subjects were always studied in the same experiment and each VLDL sample was incubated in triplicate. The lipid composition (free and esterified cholesterol, triglycerides and phospholipids) and apoprotein composition were measured in each VLDL sample.

\section{Endothelial cell isolation and culture}

Human umbilical vein endothelial cells were isolated from umbilical cords obtained from the Medical University of South Carolina Delivery Room. Cords were obtained as soon as possible after normal vaginal delivery and were placed in ice-cold cord buffer $(0.14 \mathrm{~mol} / 1$ $\mathrm{NaCl}, 0.004 \mathrm{~mol} / 1 \mathrm{KCl}, 0.001 \mathrm{~mol} / \mathrm{l} \mathrm{NaPO}_{4}, \mathrm{pH} 7.35$ ). The umbilical vein in undamaged cord segments was identified, was cannulated with a $2.54 \mathrm{~cm}$ straight, ball-tipped rat intubation tube which was then secured in the cord. The cord was flushed with cold cord buffer to remove blood. The other end of the vein was cannulated with a similar feeding tube which had rubber tubing attached. The vein was then flushed with additional cord buffer through the second cannula. The vein was filled with enough warm $0.1 \%$ collagenase (type 1 from Clostrodium histolyticum, Sigma Chemical Co., St. Louis, Mo., USA) in cord buffer (approximately $10 \mathrm{ml}$ ) to slightly distend it and the rubber tubing was clamped. The cord was placed in a sterile vessel containing cord buffer at $37^{\circ} \mathrm{C}$, covered with sterile aluminum foil and incubated for $15 \mathrm{~min}$ at $37^{\circ} \mathrm{C}$. After the incubation, the cord was gently kneaded two times up and down its length and the collagenase solution flushed out of the vein with $30 \mathrm{ml}$ cord buffer into a sterile $50 \mathrm{ml}$ conical, plastic centrifuge tube containing $10 \mathrm{ml}$ of a solution of $50 \%$ ((volume/volume,v/v)) bovine calf serum (Sigma Chemical Co.) and Iscove's modified Dulbecco's medium (IMDM) (Gibco, Grand Island, NY, USA). The isolated cells were pelleted by centrifugation for $5 \mathrm{~min}$ at $250 \times \mathrm{g}$ and the supernatant decanted. The endothelial cell pellet was gently resuspended in an endothelial cell growth medium (growth medium) with the following composition: IMDM containing human serum (Whittaker MA Bioproducts, Walkersville, Md., USA) $(10 \%, \mathrm{v} / \mathrm{v})$ previously heat inactivated by incubation at $56^{\circ} \mathrm{C}$ for $45 \mathrm{~min}$, heat inactivated fetal bovine serum $(10 \%, \mathrm{v} / \mathrm{v})$ (Sigma Chemical Co.), $5 \mathrm{U} / \mathrm{ml}$ catalase, $4 \mathrm{~mol} / 1$ glutamine, $1 \mu \mathrm{g} / \mathrm{ml}$ transferrin, $100 \mathrm{U} / \mathrm{ml}$ penicillin, $100 \mu \mathrm{g} / \mathrm{ml}$ streptomycin, $2.5 \mu \mathrm{g} / \mathrm{ml}$ amphotericin B and $150 \mu \mathrm{g} / \mathrm{ml}$ endothelial cell growth supplement (Sigma Chemical Co.) and transferred to a T-25 culture flask with the growth surface previously coated with gelatin 
( $1 \%$, weight/volume (w/v), porcine skin, type II, 175 bloom $)$. Cells were incubated at $37^{\circ} \mathrm{C}$ in a humidified atmosphere of $95 / 5 \%$ air $/ \mathrm{CO}_{2}$ and the medium was removed and replenished with medium of the same composition every 2-3 days. Cells generally grew to confluence in 3-4 days and were subcultured at a $1: 3$ ratio. To subculture the cells, the culture was harvested with trypsin-EDTA $(0.05 \%$ : $0.02 \%$ ) at $37^{\circ} \mathrm{C}$. Cells were used for experimentation only after $2-4$ passages. The endothelial identity of the cells is confirmed by visual observation of the "cobblestone" growth pattern and the presence of factor VIII antigen [20]. All experiments were conducted 3 days after the culture reached confluence.

\section{$V L D L$ subfraction isolation and composition}

Blood for the isolation of VLDL subfractions was collected in the presence of a lipoprotein preservative solution containing EDTA $(0.1 \%$, w/v), chloramphenicol $(20 \mu \mathrm{g} / \mathrm{ml})$, gentamycin sulphate $(50 \mu \mathrm{g} / \mathrm{ml})$ and $\varepsilon$-amino-caproic acid $(0.13 \%$, w/v) (final concentrations). After the blood cells were sedimented by low speed centrifugation, the following chemicals were added to plasma at the indicated final concentrations to retard proteolysis: phenylmethylsulphonylfluoride (PMSF, $20 \mu \mathrm{g} / \mathrm{ml}$, Sigma Chemical Co.), D-phenylalanyl-L-prolyl-L-arginine chloromethyl ketone (PPACK, $1 \mu \mathrm{mol} /$, Calbiochem-Behring, La Jolla, Calif., USA), and aprotinin $(1 \mu \mathrm{g} / \mathrm{ml}$, Sigma Chemical Co.).

VLDL (density $(\mathrm{d})<1.006 \mathrm{~g} / \mathrm{ml}$ ) were isolated from plasma at $10^{\circ} \mathrm{C}$ by ultracentrifugation at $60,000 \mathrm{rev} / \mathrm{min}$ for $18 \mathrm{~h}$ in a $60 \mathrm{Ti}$ rotor (Beckman Instruments Inc., Palo Alto, Calif. USA). The floating VLDL was removed after tube slicing and this VLDL solution was used for the isolation of VLDL subfractions. The following subfractions of VLDL were isolated by cumulative flotation ultracentrifugation (Beckman SW 41 rotor) exactly as described [21]: VLDL-I (V-I), $\mathrm{S}_{\mathrm{f}} 100-400\left(\mathrm{~S}_{\mathrm{f}}=\right.$ Svedberg units); VLDL-II (V-II), $\mathrm{S}_{\mathrm{f}} 60-100$; VLDL-III (V-III), $S_{\mathrm{f}} 20-60$. The isolated VLDL subfractions were dialysed against $0.9 \% \mathrm{NaCl}, 0.01 \%$ EDTA (w/v), pH 7.4. Salt solutions used to adjust the solvent densities also contained $0.01 \%$ EDTA, $\mathrm{pH}$ 7.4. The lipoprotein preparations were sterilized by passage through a $0.2 \mu \mathrm{m}$. filter (Gelman Sciences, Ann Arbor, Mich., $\mathrm{USA}$ ) and stored at $4{ }^{\circ} \mathrm{C}$ under a $\mathrm{N}_{2}$ atmosphere.

Aliquots of the isolated VLDL fractions were extracted with chloroform/methanol $(2: 1, \mathrm{v} / \mathrm{v})[22]$. The free and total cholesterol [23], triglyceride [24], phospholipid phosphorus [25], and total protein [26] concentrations of the lipoprotein samples were determined as described previously [10]. Lipoprotein lipid oxidation was determined by quantitating the amount of thiobarbituric acid reducing substances in each sample [27].

The apoprotein composition of VLDL was examined using quantitative immunoelectrophoresis and RIA. VLDL apoprotein B concentrations were determined using quantitative immunoelectrophoresis, with LDL $(1.03<\mathrm{d}<1.05)$ as the standard [4]. We have standardized this assay through our participation in an international collaborative study initiated by the Centers for Disease Control (CDC) and sponsored by the Standardization Committee of the International Union of Immunological Societies (IUIS) [28, 29]. Our results compare well with those reported by other investigators with an average coefficient of variation for our assay of less than $5.9 \%$. VLDL apoprotein E concentrations were kindly determined by Dr. T. Cole (Lipid Research Center, Washington University School of Medicine, St. Louis, Mo., USA) by RIA [30]. The average coefficient of variation for this assay is less than $6.1 \%$. The concentration of apoprotein $\mathrm{C}$ was calculated as the difference between the total protein concentration of VLDL (apoproteins B, E and C) minus the sum of the concentrations of apoprotein $B$ plus apoprotein $E$.

To determine if isolation of the individual VLDL subfractions by ultracentrifugation resulted in modifications of the apoprotein composition of the fractions, especially through loss of apoprotein E, the following studies were conducted. The triglyceride rich lipoprotein fraction was isolated by agarose column chromatography [31] of whole plasma obtained from two fasting, diabetic patients and two fasting, control subjects. Lipoproteins eluting in peak one were pooled and concentrated and an aliquot was subjected to the ultracentrifugation conditions described above for the isolation of VLDL subfractions. Lipoproteins floating as VLDL-I, VLDL-II and VLDL-III were pooled for subsequent analysis. We examined the apoprotein $\mathrm{B}$ /apoprotein $\mathrm{E}$ of the ultracentrifugally isolated lipoproteins and compared it to the triglyceride rich lipoproteins isolated by column chromatography. The mean apoprotein B/apoprotein $\mathrm{E}$ ratio was similar for lipoproteins isolated by both methods (data not shown) suggesting that there was no significant loss of apoprotein E during the isolation of the VLDL subfractions.

\section{VLDL accumulation and degradation studies}

Aliquots of total VLDL or each VLDL subfraction isolated from each diabetic patient and control subject were radiolabelled with ${ }^{125} I$ as described previously [9]. To conduct an experiment, endothelial cells were grown to confluence in 24-well cluster culture plates. Three days later, the growth medium was removed and each culture was washed with $1 \mathrm{ml}$ IMDM medium and $1 \mathrm{ml}$ of growth medium without serum but containing $0.15 \%(\mathrm{w} / \mathrm{v})$ bovine serum albumin (Sigma Chemical Co.) was then added to each culture. ${ }^{125} \mathrm{I}$ radiolabelled total VLDL or VLDL subfractions $(10 \mu \mathrm{g} / \mathrm{ml})$ with or without non-radiolabelled total VLDL $(250 \mu \mathrm{g} / \mathrm{ml})$ isolated from the same subject was added to the medium and the cultures were incubated at $37^{\circ} \mathrm{C}$ for $16 \mathrm{~h}$. The proteolytic degradation of ${ }^{125} \mathrm{I}-\mathrm{VLDL}$ by human endothelial cells was measured by assaying the amount of ${ }^{125}$ I-trichloroacetic-soluble (non-iodide) material formed by the cells and excreted into the culture medium as described previously [9]. Rates of total degradation were determined in incubations containing only ${ }^{125}$ I-VLDL and the rates of non-specific degradation were determined in parallel incubations containing a 25 -fold excess of non-radiolabelled, total VLDL. Receptor-mediated degradation rates were calculated as the difference between total and non-specific degradation rates. The intracellular accumulation of ${ }^{125} \mathrm{I}-\mathrm{VLDL}$ was determined after removing the medium and washing the cultures. The cells were then dissolved in $1 \mathrm{ml}$ of $0.2 \mathrm{~mol} / 1 \mathrm{NaOH}$ and the amount of ${ }^{125}$ I radioactivity associated with the cells was determined. An aliquot of the solubilized cells was taken from each well for determination of cellular protein content as described previously [9].

\section{Other methods}

Plasma glucose was assayed by the glucose oxidase method, as adapted for use in the Beckman glucose analyser [32]. $\mathrm{HbA}_{1 \mathrm{c}}$ was measured by cation exchange chromatography of erythrocyte haemolysates (Hemoglobin $A_{1 c}$ Micro Column Test. Bio-Rad Laboratories, Hercules, Calif, USA). C-peptide levels in plasma were determined using a double-antibody RIA (C-Peptide; Diagnostic Products Corporation, Los Angeles, Calif., USA). Plasma HDL, cholesterol concentration was determined after precipitating VLDL and LDL with sodium phosphotungstate/magnesium chloride as described previously [33]. Total cholesterol in whole plasma and lipoprotein fractions was measured using a continuous-flow analyzer (AutoAnalyzer I; Technicon Instruments, Tarrytown, NY, USA) with the chemically based Liebermann-Burchard method of analysis standardized by the Lipid Research Clinics Program [24] in their Manual of Laboratory Operations. Triglycerides in these fractions were assayed using a semi-automated, enzymatic method (Triglyceride Stat-Pak; Calbiochem-Behring) outlined in the same manual [24].

\section{Statistical analysis}

Data from paired observations was analysed with the Wilcoxon signed-rank test. These analyses were determined with the Instat software program (GraphPad, San Diego, Calif., USA). 
Table 3. Rates of degradation and accumulation of VLDL subfractions isolated from Type 1 diabetic patients and control subjects by human endothelial cells

\begin{tabular}{|c|c|c|c|c|c|c|c|c|}
\hline \multirow{3}{*}{$\begin{array}{l}\text { VLDL } \\
\text { Subfraction }\end{array}$} & \multicolumn{4}{|c|}{ Degradation } & \multicolumn{4}{|c|}{ Accumulation } \\
\hline & \multicolumn{2}{|c|}{ Receptor-mediated } & \multicolumn{2}{|c|}{ Non-specific } & \multicolumn{2}{|c|}{ Receptor-mediated } & \multicolumn{2}{|c|}{ Non-specific } \\
\hline & Control & Diabetic & Control & Diabetic & Control & Diabetic & Control & Diabetic \\
\hline V-II & $\begin{array}{c}294^{c} \\
\pm 70\end{array}$ & $\begin{array}{l}433 \\
\pm 70\end{array}$ & $\begin{array}{l}285 \\
\pm 74\end{array}$ & $\begin{array}{l}390 \\
\pm 120\end{array}$ & $\begin{array}{c}598^{\circ} \\
\pm 75\end{array}$ & $\begin{array}{l}778 \\
\pm 266\end{array}$ & $\begin{array}{l}49 \\
\pm 20\end{array}$ & $\begin{array}{l}57 \\
\pm 10\end{array}$ \\
\hline
\end{tabular}

${ }^{\mathrm{a}}$ Mean $\pm \mathrm{SEM}$; rates expressed as $\mathrm{ng} \cdot \mathrm{mg}$ cell protein $^{-1} \cdot 16 \mathrm{~h}^{-1}$;

${ }^{\mathrm{b}} p<0.01,{ }^{\mathrm{c}} p<0.05 \mathrm{vs}$ high affinity degradation of subfraction isolated from diabetic patient;

${ }^{\mathrm{d}} p<0.01,{ }^{\mathrm{e}} p<0.05$ vs high affinity accumulation of subfraction isolated from diabetic patient

Table 4. Chemical composition and plasma concentration of VLDL subfractions isolated from Type 1 diabetic patients and control subjects

\begin{tabular}{|c|c|c|c|c|c|c|c|}
\hline \multirow[t]{2}{*}{ Lipoprotein } & \multirow[t]{2}{*}{ Subjects } & \multicolumn{5}{|c|}{$\%$ mass } & \multirow{2}{*}{$\begin{array}{l}\text { Lipoprotein concentration } \\
(\mathrm{mg} / \mathrm{dl})\end{array}$} \\
\hline & & $\overline{\mathrm{PRO}}$ & $\mathrm{FC}$ & $\mathrm{CE}$ & TG & $\mathrm{PL}$ & \\
\hline V-I & $\begin{array}{l}\text { Control } \\
\text { Diabetic }\end{array}$ & $\begin{array}{l}6.0^{\mathrm{a}} \\
\pm 0.9 \\
4.7 \\
\pm 0.6\end{array}$ & $\begin{array}{l}5.0 \\
\pm 1.1 \\
5.6 \\
\pm 1.8\end{array}$ & $\begin{array}{l}7.0 \\
\pm 0.5 \\
6.7 \\
\pm 1.5\end{array}$ & $\begin{array}{l}68.6 \\
\pm 1.4 \\
68.5 \\
\pm 3.9\end{array}$ & $\begin{array}{l}13.4 \\
\pm 0.9 \\
14.5 \\
\pm 0.9\end{array}$ & $\begin{array}{l}97.5 \\
\pm 14.7 \\
80.9 \\
\pm 19.9\end{array}$ \\
\hline V-II & $\begin{array}{l}\text { Control } \\
\text { Diabetic }\end{array}$ & $\begin{array}{l}8.0 \\
\pm 0.7 \\
6.5 \\
\pm 0.9\end{array}$ & $\begin{array}{l}5.8 \\
\pm 0.9 \\
5.4 \\
\pm 0.8\end{array}$ & $\begin{array}{l}7.8 \\
\pm 0.4 \\
7.3 \\
\pm 0.8\end{array}$ & $\begin{array}{l}60.4 \\
\pm 1.7 \\
63.2 \\
\pm 1.8\end{array}$ & $\begin{array}{l}18.0 \\
\pm 0.8 \\
17.6 \\
\pm 0.9\end{array}$ & $\begin{array}{l}72.5 \\
\pm 10.0 \\
68.1 \\
\pm 11.8\end{array}$ \\
\hline V-III & $\begin{array}{l}\text { Control } \\
\text { Diabetic }\end{array}$ & $\begin{array}{l}10.2 \\
\pm 0.5 \\
11.0 \\
\pm 0.1\end{array}$ & $\begin{array}{l}4.4 \\
\pm 0.3 \\
5.3 \\
\pm 0.2\end{array}$ & $\begin{array}{l}14.4 \\
\pm 1.1 \\
14.4 \\
\pm 1.1\end{array}$ & $\begin{array}{l}52.0 \\
\pm 2.0 \\
48.2 \\
\pm 1.5\end{array}$ & $\begin{array}{l}19.0 \\
\pm 1.6 \\
21.1 \\
\pm 1.1\end{array}$ & $\begin{array}{l}130.8 \\
\pm 19.4 \\
121.5 \\
\pm 14.5\end{array}$ \\
\hline
\end{tabular}

${ }^{a}$ Mean \pm SEM;

${ }^{b}$ Determined as sum of plasma concentrations of individual lipid and total protein components.

PRO, Protein; FC, free (unesterified) cholesterol; CE, cholesteryl ester ( = $1.7 \times$ esterified cholesterol); TG, triglyceride; PL, phospholipid

\section{Results}

We investigated the interaction of VLDL with endothelial cell lipoprotein receptors by determining the rates of degradation of ${ }^{125} \mathrm{I}-\mathrm{VLDL}$ isolated from the diabetic patients and control subjects. When the total VLDL $(\mathrm{d}<1.006$ $\mathrm{g} / \mathrm{ml}$ ) fraction was incubated with endothelial cells, the rate of receptor-mediated degradation by endothelial cells was significantly greater $(p<0.02)$ for VLDL isolated from diabetic patients compared to control subjects and averaged $1008 \pm 300$ and $717 \pm 150 \mathrm{ng} \cdot \mathrm{mg}$ cell protein ${ }^{-1}$. $16 \mathrm{~h}^{-1}$, respectively. Rates of non-specific degradation of the total VLDL fraction by endothelial cells did not differ significantly and averaged $741 \pm 150$ and $549 \pm 100 \mathrm{ng} \cdot \mathrm{mg}$ cell protein ${ }^{-1} \cdot 16 \mathrm{~h}^{-1}$, respectively. The rate of receptormediated accumulation by endothelial cells of the total VLDL fraction was also significantly greater $(p<0.05)$ for VLDL isolated from diabetic patients compared with control subjects and averaged $1097 \pm 250$ and $677 \pm 150 \mathrm{ng} \cdot \mathrm{mg}$ cell protein ${ }^{-1} \cdot 16 \mathrm{~h}^{-1}$, respectively. Rates of non-specific accumulation of the total VLDL fraction by endothelial cells also did not differ significantly and averaged $182 \pm 67$ and $210 \pm 72 \mathrm{ng} \cdot \mathrm{mg}$ cell protein $\mathrm{n}^{-1} \cdot 16 \mathrm{~h}^{-1}$, for diabetic patients and control subjects, respectively.

To determine if the increase in the rates of receptormediated degradation by endothelial cells of VLDL iso- lated from diabetic patients was confined to particles of a specific size, we separated the total VLDL fraction from each subject into three discretely sized populations based on the rate of flotation of the particle in a salt gradient. There was a significant increase in the rates of receptormediated degradation of V-I $(p<0.01)$ and V-II $(p<0.03)$ isolated from diabetic patients as shown by the data in Table 3. Rates of receptor-mediated degradation of the V-III subfraction isolated from the two groups did not differ significantly and are also shown in Table 3 . There was also a significant increase in the rate of receptor-mediated accumulation of V-I $(p<0.01)$ and V-II $(p<0.05)$ isolated from diabetic patients compared to control subjects and these results are detailed in Table 3. Rates of accumulation of the V-III subfraction isolated from the two groups did not differ significantly.

To determine if the increased rates of degradation of VLDL-I and VLDL-II isolated from diabetic patients were associated with changes in the chemical composition of the subfraction, we analysed the lipid and protein composition of each VLDL subfraction. The chemical compositions of the VLDL subfractions isolated from the diabetic patients and control subjects are shown in Table 4. There were no significant differences in the chemical composition of the V-I, V-II and V-III subfractions isolated from diabetic patients compared to control subjects. There were also no sig- 
Table 5. Composition and plasma concentration of apoproteins (apo) in VLDL subfractions isolated from Type 1 diabetic patients and control subjects

\begin{tabular}{|c|c|c|c|c|c|c|c|c|c|c|}
\hline \multirow[t]{2}{*}{ Lipoprotein } & \multirow[t]{2}{*}{ Subjects } & \multicolumn{3}{|l|}{$\%$ mass } & \multicolumn{3}{|c|}{ Ratio of constituents } & \multicolumn{3}{|c|}{ Apoprotein concentration $(\mathrm{mg} / \mathrm{dl})$} \\
\hline & & Apo B & Apo E & Apo C & $\mathrm{B} / \mathrm{E}$ & $\mathrm{B} / \mathrm{C}$ & $\mathrm{C} / \mathrm{E}$ & Apo B & Apo E & Apo C \\
\hline V-I & $\begin{array}{l}\text { Control } \\
\text { Diabetic }\end{array}$ & $\begin{array}{l}53.0 \\
\pm 1.5 \\
47.4 \\
\pm 2.4\end{array}$ & $\begin{array}{l}4.1 \\
\pm 0.7 \\
6.9 \\
\pm 1.0\end{array}$ & $\begin{array}{l}42.9 \\
\pm 1.9 \\
45.7 \\
\pm 2.4\end{array}$ & $\begin{array}{l}14.3^{\mathrm{b}} \\
\pm 1.7 \\
8.2 \\
\pm 1.6\end{array}$ & $\begin{array}{l}1.3 \\
\pm 0.1 \\
1.1 \\
\pm 0.1\end{array}$ & $\begin{array}{l}11.8^{c} \\
\pm 1.7 \\
7.9 \\
\pm 1.4\end{array}$ & $\begin{array}{l}2.6 \\
\pm 0.8 \\
1.7 \\
\pm 0.4\end{array}$ & $\begin{array}{l}0.3 \\
\pm 0.1 \\
0.2 \\
\pm 0.1\end{array}$ & $\begin{array}{l}2.0 \\
\pm 0.7 \\
1.5 \\
\pm 0.1\end{array}$ \\
\hline V-II & $\begin{array}{l}\text { Control } \\
\text { Diabetic }\end{array}$ & $\begin{array}{l}54.3 \\
\pm 3.0 \\
53.9 \\
\pm 3.7\end{array}$ & $\begin{array}{l}3.0 \\
\pm 0.5 \\
3.7 \\
\pm 0.5\end{array}$ & $\begin{array}{l}42.7 \\
\pm 2.7 \\
42.5 \\
\pm 3.8\end{array}$ & $\begin{array}{l}21.1^{\mathrm{d}} \\
\pm 4.8 \\
15.9 \\
\pm 2.5\end{array}$ & $\begin{array}{l}1.3 \\
\pm 0.2 \\
1.3 \\
\pm 0.2\end{array}$ & $\begin{array}{l}15.5 \\
\pm 2.1 \\
12.6 \\
\pm 2.0\end{array}$ & $\begin{array}{l}2.9 \\
\pm 1.1 \\
2.7 \\
\pm 0.9\end{array}$ & $\begin{array}{l}0.2 \\
\pm 0.1 \\
0.2 \\
\pm 0.1\end{array}$ & $\begin{array}{l}2.5 \\
\pm 1.0 \\
2.0 \\
\pm 0.7\end{array}$ \\
\hline V-III & $\begin{array}{l}\text { Control } \\
\text { Diabetic }\end{array}$ & $\begin{array}{l}59.1 \\
\pm 7.0 \\
56.8 \\
\pm 4.0\end{array}$ & $\begin{array}{l}1.6 \\
\pm 0.3 \\
1.8 \\
\pm 0.2\end{array}$ & $\begin{array}{l}39.3 \\
\pm 6.0 \\
41.4 \\
\pm 4.2\end{array}$ & $\begin{array}{l}43.0 \\
\pm 10.4 \\
32.3 \\
\pm 1.5\end{array}$ & $\begin{array}{l}1.9 \\
\pm 0.4 \\
1.5 \\
\pm 0.3\end{array}$ & $\begin{array}{l}28.0 \\
\pm 4.0 \\
24.7 \\
\pm 4.4\end{array}$ & $\begin{array}{l}8.6 \\
\pm 1.6 \\
7.6 \\
\pm 1.2\end{array}$ & $\begin{array}{l}0.3 \\
\pm 0.1 \\
0.2 \\
\pm 0.1\end{array}$ & $\begin{array}{l}6.8 \\
\pm 0.8 \\
6.5 \\
\pm 0.8\end{array}$ \\
\hline
\end{tabular}

${ }^{\mathrm{a}}$ Mean \pm SEM;

${ }^{\mathrm{b}} p<0.01,{ }^{\mathrm{c}} p<0.03$ vs V-I fraction of diabetic group;

d $p<0.05$ vs V-II fraction of diabetic group

nificant differences in the plasma concentrations of the three subfractions in diabetic patients compared to control subjects as shown in Table 4. We also analysed the extent of oxidation of the subfraction lipids by determining the amount of thiobarbituric acid reacting substances in the VLDL subfractions isolated from each subject. There were no significant differences in the amounts of thiobarbituric acid reacting substances in the subfractions isolated from diabetic patients compared to control subjects and these levels averaged $0.10 \pm 0.02$ vs $0.15 \pm 0.06 \mathrm{nmol} / \mathrm{mg}$ lipoprotein protein, respectively for the V-I subfraction, $0.13 \pm 0.04 \mathrm{vs} 0.19 \pm 0.08 \mathrm{nmol} / \mathrm{mg}$ lipoprotein protein for the V-II subfraction and $0.51 \pm 0.20 \mathrm{vs} 0.37 \pm 0.30 \mathrm{nmol} / \mathrm{mg}$ lipoprotein protein for the V-III subfraction.

The apoprotein composition of the three subfractions was also analysed and these results are shown in Table 5. The V-I subfraction isolated from diabetic patients was enriched in apoprotein $\mathrm{E}$ as shown by the significant decrease in the apoprotein $\mathrm{B} /$ apoprotein $\mathrm{E}$ ratio $(p<0.01)$. There was also a significant increase in the apoprotein C/apoprotein $\mathrm{E}$ ratio $(p<0.03)$ in the $\mathrm{V}$-I fraction isolated from control subjects compared to the diabetic patients. Similarly, there was a significant increase in the apoprotein $\mathrm{B} /$ apoprotein E ratio $(p<0.05)$ in the V-II subfraction isolated from diabetic patients. There was no increase in the apoprotein C/apoprotein E ratio in the V-II fraction isolated from control subjects compared to the diabetic patients. There were no significant differences in the apoprotein composition of the V-III subfraction isolated from diabetic patients compared to control subjects.

\section{Discussion}

The results of the present study suggest that the metabolic behaviour of VLDL is significantly altered in Type 1 diabetic patients. Human endothelial cells degraded and accumulated significantly more VLDL isolated from Type 1 diabetic patients compared with VLDL isolated from matched control subjects. Furthermore, the increased degradation was specific for the largersized VLDL particles. This suggests the presence of an alteration in lipoprotein metabolism in Type 1 diabetic patients, even in patients who are in fair to good glycaemic control and whose plasma lipid and lipoprotein levels are normal.

The observed increases in the rates of degradation and accumulation by endothelial cells of the large sized V-I and V-II subfractions isolated from diabetic patients were not associated with changes in the chemical composition of the VLDL subfractions. We [9] and others [34] have previously reported an increase in the free cholesterol content of the total VLDL fraction isolated from Type 1 diabetic patients. We have shown that the free cholesterol content of VLDL isolated from Type 1 diabetic patients decreases with improved levels of glycaemic control [35]. The free cholesterol content of the V-I subfraction isolated from a group of poorly-controlled Type 1 diabetic patients both before and after glycaemic control was attained was significantly greater than that in the V-I subfraction isolated from non-diabetic, control subjects [18]. The cause of the apparent discrepancy between the results of the present study and those of these previous studies is not readily apparent. However, because VLDL free cholesterol content is associated with the level of glycaemic control and because the patients in the present study demonstrated much better levels of glycaemic control than did those in these previous studies, the level of glycaemic control in this population of diabetic patients may be a contributing factor.

We also analysed the apoprotein composition of the VLDL subfractions to identify factors responsible for the increased degradation by endothelial cells of the subfractions isolated from the diabetic patients. The V-I and V-II subfractions isolated from the diabetic patients were significantly enriched in apoprotein $E$. It has been shown repeatedly that apoprotein E molecules on VLDL serve as a ligand for the interaction of the particle with cell receptors [36-38]. Recent studies have shown that the enrichment of normal VLDL with apoprotein E significantly increases the catabolism of the VLDL by fibroblasts [39] and by macrophages $[39,40]$. Thus, the increased apoprotein $E$ content of V-I and V-II isolated from the diabetic patients may have resulted in increased recognition of the particles by 
endothelial cell lipoprotein receptors and thereby stimulated the catabolism of these large sized VLDL particles. In addition, previous studies have shown that VLDL isolated from fasting hypertriglyceridaemic subjects are degraded more rapidly than VLDL isolated from fasting subjects with normal triglyceride levels [36]. Additional studies showed that it is a unique orientation of apoprotein $\mathrm{E}$ on the surface of V-I isolated from hypertriglyceridaemic patients which mediates the uptake of the large V-I particles [41] and that the determinants for the binding of these VLDL to the LDL receptor switch from apoprotein $E$ for $\mathrm{V}$-I sized particles to apoprotein B for V-III sized particles [42]. The diabetic state may modify the apoprotein Emolecules on the surface of V-I and V-II making the conformation of apoprotein $\mathrm{E}$ on the VLDL subfractions isolated from diabetic patients more similar to those isolated from hypertriglyceridaemic patients. More of the lysine residues of apoprotein $\mathrm{E}$ in VLDL isolated from diabetic patients are glycated than those from non-diabetic patients [17]. Individual epitopes of apoprotein $E$ can be modulated, perhaps by glycation, and differences in apoprotein $E$ conformation may significantly influence the metabolism of the lipoprotein $[43,44]$. Thus, glycation of VLDL apoproteins, especially apoprotein E in large sized VLDL particles whose receptor binding determinant is apoprotein $\mathrm{E}$, may alter the interaction of the lipoprotein with cell receptors.

The phenotype of apoprotein E on VLDL may influence its interaction with lipoprotein receptors. Unfortunately, sufficient material was not available for analysis of apoprotein E phenotype after the extensive analyses of lipoprotein composition and metabolism were completed. However, recent studies have shown the phenotype of apoprotein $E$ from Type 1 and Type 2 diabetic patients to be similar to that of non-diabetic subjects [45-47]. In addition, the apoprotein $\mathrm{E}$ allele distribution is similar in diabetic patients and control subjects [48]. Therefore, the apoprotein $\mathrm{E}$ phenotype of VLDL isolated from the diabetic patients in the present study presumably did not influence the interaction of the particles with endothelial cell lipoprotein receptors.

The contribution of this altered interaction between the V-I subfraction and endothelial cells to atherogenesis in diabetes remains to be demonstrated. However, alterations in the capacity of vascular endothelium to release either tissue plasminogen activator or plasminogen activator inhibitor-1 play an important role in the occurrence of thrombosis. Recent evidence suggests that VLDL may alter the secretion of these two critical proteins. The secretion of plasminogen activator inhibitor- 1 has been shown to be induced by VLDL [49]. Furthermore, this enhanced secretion is dependent on the binding of VLDL to the native LDL receptor. In addition, VLDL isolated from normal, but not hypertriglyceridaemic patients, stimulate the release of tissue plasminogen activator from endothelial cells and this stimulus is localized to the large sized VLDL particles [50]. The effect of VLDL with altered apoprotein composition and with apoproteins modified by glycation on the release by endothelial cells of these proteins which regulate fibrinolysis remains to be demonstrated.

In conclusion, we have shown that VLDL, especially the large sized particles, isolated from Type 1 diabetic pa- tients interact abnormally with human endothelial cells. Furthermore, this altered interaction was observed with VLDL isolated from patients in good to fair glycaemic control. The effect of this altered cell-lipoprotein interaction on endothelial cell metabolism and its role in the pathogenesis of atherosclerosis in diabetes remain to be determined.

Acknowledgements. We gratefully acknowledge the expert technical assistance of Ms. C. Chassereau and Mr. T. Williams. This work was supported by the Research Service of the Department of Veteran Affairs.

\section{References}

1. West KM (1982) Hyperglycemia as a cause of long-term complications. In: Keen H, Jarrett RJ (eds) Complications of diabetes. Edward Arnold, London, pp 13-18

2. Garcia MJ, McNamara PM, Gordon T, Kannel WB (1974) Morbidity and mortality in diabetes in the Framingham population. Diabetes 23: 105-111

3. Barrett-Conner E, Orchard T (1985) Diabetes and heart disease. In: Harris ME, Hamman RF (eds) National diabetes data group, diabetes in America. National Institutes of Health Publication No. 85-1468. U.S. Department of Health and Human Services, Washington, DC, pp $63-69$

4. Lopes-Virella MF, Sherer GK, Lees AM et al. (1982) Surface binding, internalization, and degradation by cultured human fibroblasts of low density lipoproteins isolated from type 1 (insulin-dependent) diabetic patients: changes with metabolic control. Diabetologia 22: $430-436$

5. Kraemer FB, Chen Y-DI, Cheung RMC, Reaven GM (1982) Are the binding and degradation of low density lipoprotein altered in type 2 (non-insulin-dependent) diabetes mellitus? Diabetologia 23: $28-33$

6. Hiramatsu K, Bierman EL, Chait A (1985) Metabolism of low density lipoprotein from patients with diabetic hypertriglyceridemia by cultured human skin fibroblasts. Diabetes 34: 8-14

7. Lopes-Virella MF, Klein RL, Lyons TJ, Stevenson HC, Witztum JL (1988) Glycation of low-density lipoproteins enhances cholesteryl ester synthesis in human monocyte macrophages. Diabetes 37: $550-557$

8. Lyons TJ, Klein RL, Baynes JW, Stevenson HC, Lopes-Virella MF (1987) Stimulation of cholesteryl ester synthesis in human monocyte-derived macrophages by low-density lipoproteins from type 1 (insulin-dependent) diabetic subjects: the influence of non-enzymatic glycosylation of low-density lipoproteins. Diabetologia 30: 916-923

9. Klein RL, Lyons TJ, Lopes-Virella MF (1989) Interaction of VLDL isolated from type 1 (insulin-dependent) diabetic subjects with human monocyte derived macrophages. Metabolism 38: 1108-1114

10. Klein RL, Lyons TJ, Lopes-Virella MF (1990) Metabolism of very low- and low-density lipoproteins isolated from normolipidaemic type 2 (non-insulin-dependent) diabetic patients by human monocyte-derived macrophages. Diabetologia 33: 299 305

11. Kraemer FB, Chen Y-DI, Lopez RD, Reaven GM (1985) Effects of non-insulin-dependent diabetes mellitus on the uptake of very low density lipoproteins by thioglycolate-elicited mouse peritoneal macrophages. J Clin Endocrinol Metab 61: 335-342

12. Coetzee GA, Stein O, Stein Y (1979) Uptake and degradation of low density lipoproteins (LDL) by confluent, contact-inhibited bovine and human endothelial cells exposed to physiological concentrations of LDL. Atherosclerosis 33: 425-431

13. van Hinsbergh VW, Havekes L, Emies JJ, van Corven E, Scheffer M (1983) Low density lipoprotein metabolism by endothelial cells from human umbilical cord arteries and veins. Arteriosclerosis 3: 547-559 
14. Baker DP, van Lenten BJ, Fogelman AM, Edwards PA, Kean C, Berliner JA (1984) LDL, scavenger, and beta-VLDL receptors on aortic endothelial cells. Arteriosclerosis 4: 248-255

15. Kume N, Arai H, Kawai C, Kita T (1991) Receptors for modified low-density lipoproteins on human endothelial cells: different recognition of acetylated low-density lipoprotein and oxidized low-density lipoprotein. Biochim Biophys Acta 1091: 63-67

16. Schleicher E, Deufeland T, Wieland OH (1981) Non-enzymatic glycosylation of human serum lipoproteins. Elevated $\varepsilon$-lysine glycosylated low density lipoprotein in diabetic subjects. FEBS Lett 124: 1-4

17. Curtiss LK, Witztum JL (1985) Plasma apolipoproteins A-I, A-II, B, C-I and E are glucosylated in hyperglycemic diabetic subjects. Diabetes 34: 452-461

18. James RW, Pometta D (1990) Differences in lipoprotein subfraction composition and distribution between type 1 diabetic men and control subjects. Diabetes 39: 1158-1164

19. National diabetes data group (1979) Classification and diagnosis of diabetes mellitus and other categories of glucose intolerance. Diabetes 28: 1039-1057

20. Jaffe EA, Hoyer LW, Nachman RL (1973) Synthesis of antihemophiliac factor by cultured human endothelial cells. J Clin Invest 52: 2757-2767

21. Lindgren FT, Jensen LC, Hatch FT (1972) The isolation and quantitative analysis of serum lipoproteins. In: Nelson GJ (ed) Blood lipids and lipoproteins: quantitation, composition and metabolism. Wiley-Interscience, New York, pp 181-274

22. Folch J, Lees M, Stanley GHS (1957) A simple method for the isolation and purification of total lipids from animal tissues. J Biol Chem 226: 497-509

23. Ishikawa TT, McGee Y, Morrison JA, Glueck CJ (1974) Quantitative analyses of cholesterol in 5 to $20 \mu$ of plasma. J Lipid Res 15: $286-291$

24. Lipid Research Clinics Program (1974) Manual of lipid operations, Vol. 1. Lipid and lipoprotein analysis. National Institutes of Health, National Heart Lung and Blood Institute, Publication No. 75-628. US Government Printing Office, Washington, DC, pp 9-37

25. Bartlett GR (1959) Phosphorus assay in column chromatography. J Biol Chem 234: 466-468

26. Markwell MAK, Haas SM, Bieber LL, Tolbert NE (1978) A modification of the Lowry procedure to simplify protein determination in membrane and lipoprotein samples. Anal Biochem $87: 206-211$

27. Ohkawa H., Ohishi N, Yagi K (1978) Reaction of linoleic acid hydroperoxide with thiobarbituric acid. J Lipid Res 19: 1053-1057

28. Smith SJ, Cooper GR, Henderson LO et al. (1987) Apolipoprotein standardization collaborating group: an international collaborative study on standardization of apolipoproteins A-I and B. Part I. Evaluation of a lyophilized candidate reference and calibration material. Clin Chem 33: 2240-2249

29. Henderson LO, Hannon WH, Smith SJ et al. (1987) An international collaborative study on standardization of apolipoproteins A-I and B. Part II. Evaluation of contributions of antisera to among-laboratory variance components. Clin Chem 33: 22502256

30. Falco JM, Schonfeld G, Witztum JL, Kolar JB, Weidman SW, Steelman R (1980) Effects of diet on apoprotein E levels and on the apoprotein E subspecies in human plasma lipoproteins. $\mathrm{J}$ Clin Endocrinol Metab 50: 521-528

31. Campos E, Makajima K, Tanaka A, Havel RJ (1992) Properties of an apolipoprotein E-enriched fraction of triglyceride-rich lipoproteins isolated from human blood plasma with a monoclonal antibody to apolipoprotein B-100. J Lipid Res 33: 369-380

32. Kadish AH, Little RL, Steinberg JC (1986) A new and rapid method for the determination of glucose by measurement of rate of oxygen consumption. Clin Chem 14: 116-131

33. Lopes-Virella MF, Stone P, Ellis S, Colwell JA (1977) Cholesterol determination in high density lipoproteins separated by three different methods. Clin Chem 23: 882-884
34. Weisweiler P, Schwandt P (1978) Type 1 (insulin-dependent) versus type 2 (non-insulin-dependent) diabetes mellitus: characterization of serum lipoprotein alterations. Eur J Clin Invest 17: $87-91$

35. Klein RL, Lopes-Virella MF (1992) Influence of glycemic control on the interaction of very low- and low density lipoproteins isolated from type 1 (insulin-dependent) diabetic patients with human monocyte-derived macrophages. Diabetes 41: 1301-1307

36. Gianturco SH, Gotto AM Jr, Jackson RL et al. (1978) Control of 3-hydroxy-3-methylglutaryl-CoA reductase activity in cultured human fibroblasts by very low density lipoproteins of subjects with hypertriglyceridemia. J Clin Invest 61:320-328

37. Wang-Iverson P, Ginsberg HN, Peteanu LA, Le N-A, Brown WV (1985) Apo E-mediated uptake and degradation of normal very low density lipoproteins by human monocyte/macrophages: a saturable pathway distinct from the LDL receptor. Biochem Biophys Res Commun 126: 578-586

38. Innerarity TL, Arnold KS, Weisgraber KH, Mahley RW (1986) Apolipoprotein $\mathrm{E}$ is the determinant that mediates the receptor uptake of $\beta$ very low density lipoproteins by mouse macrophages. Arteriosclerosis 6: 114120

39. Mokuno H, Yamada N, Shimano H et al. (1991) The enhanced cellular uptake of very-low-density lipoprotein enriched in apolipoprotein E. Biochim Biophys Acta 1082: 63-70

40. Granot E, Eisenberg S (1990) ApoE-3-specific metabolism of human plasma very low density lipoproteins in cultured $\mathbf{J}$-774 macrophages. J Lipid Res 31: 2133-2139

41. Gianturco SH, Gotto AM Jr, Hwang S-LC et al. (1983) Apolipoprotein $E$ mediates uptake of $S_{F} 100-400$ hypertriglyceridemic very low density lipoproteins by the low density lipoprotein receptor pathway in normal human fibroblasts. J Biol Chem 258: $4526-4533$

42. Bradley WA, Hwang S-LC, Karlin JB et al. (1984) Low-density lipoprotein receptor binding determinants switch from apolipoprotein $E$ to apolipoprotein $B$ during the conversion of hypertriglyceridemic very-low-density lipoprotein to low-density lipoproteins. J Biol Chem 259: 14728-14735

43. Krul ES, Tikkanen MJ, Cole TG, Davie JM, Schonfeld G (1985) Role of apolipoproteins $\mathrm{B}$ and $\mathrm{E}$ in the cellular binding of very low density lipoproteins. J Clin Invest 75: 361-369

44. Krul ES, Tikkanen MJ, Schonfeld G (1988) Heterogeneity of apolipoprotein $\mathrm{E}$ epitope expression on human lipoproteins: importance for apolipoprotein E function. J Lipid Res 29:13091325

45. Black SC, Hewett S, Kotubi Y, Brunt RV, Reckless JPD (1990) Isoform pattems of apolipoprotein $\mathrm{E}$ in diabetes mellitus. Diabetic Med 7: 532-539

46. Sano R, Abe R, Oikawa S-I, Fujii Y, Toyota T (1985) Apolipoprotein E2/E3 ratio of very low density lipoproteins in diabetes mellitus. Tohoku J Exp Med 146: 131-136

47. Eto M, Watanabe K, Iwashima Y et al. (1986) Apolipoprotein E polymorphism and hyperlipidaemia in type II diabetes. Diabetes 35: 1374-1382

48. James RW, Voliotis C, Grab B, Pometta D (1987) Apoprotein E (apo E) phenotype and serum lipids in diabetics. Schweiz Med Wochenschr 117:2021-2023

49. Sitko-Rahm A, Wiman B, Hamsten A, Nilsson J (1990) Secretion of plasminogen activator inhibitor-1 from cultured human umbilical vein endothelial cells is induced by very low density lipoprotein. Arteriosclerosis 10: 1067-1073

50. Booyse FM, Bruce R, Gianturco SH, Bradley WA (1988) Normal but not hypertriglyceridemic very low-density lipoprotein induces rapid release of tissue plasminogen activator from cultured human umbilical vein endothelial cells. Semin Thromb Hemost 14: 175-179

Received: 13 April 1992 and in final revised form: 9 November 1992

Dr. R.L. Klein, Research Service (151)

Veterans Administration Medical Center

109 Bee Street, Charleston, SC, 29401-5799, USA 